\title{
Effects of 5-Aminolevulinic Acid (ALA) on Zinnia hybrida Growth and Phytoremediation Effects in Oil-Contaminated Soil
}

\author{
Takamitsu Kai ${ }^{1}$, Hiromi Ikeura² ${ }^{2}$, Ariaki Ayanokoji ${ }^{3}$, Masahiko Tamakii ${ }^{*}$ \\ ${ }^{1}$ Kurokawa Field Science Center, Meiji University, Kawasaki, Japan \\ ${ }^{2}$ Life and Environmental Sciences Department, Shimane University, Matsue, Japan \\ ${ }^{3}$ School of Agriculture, Meiji University, Kawasaki, Japan \\ Email: *mtamaki@meiji.ac.jp
}

How to cite this paper: Kai, T., Ikeura, H., Ayanokoji, A. and Tamaki, M. (2020) Effects of 5-Aminolevulinic Acid (ALA) on Zinnia hybrida Growth and Phytoremediation Effects in Oil-Contaminated Soil. Journal of Agricultural Chemistry and Environment, 9, 97-106.

https://doi.org/10.4236/jacen.2020.93009

Received: July 15, 2020

Accepted: August 8, 2020

Published: August 11, 2020

Copyright $\odot 2020$ by author(s) and Scientific Research Publishing Inc. This work is licensed under the Creative Commons Attribution International License (CC BY 4.0).

http://creativecommons.org/licenses/by/4.0/

(c) (i) Open Access

\begin{abstract}
In this study, we compared plant height, weight, soil TPH concentration, and soil DHA level after 18 weeks of Zennia hybrida cultivation with four different concentrations of 5-Aminolevulinic acid (ALA)-based liquid fertilizer: 1500-fold, 5000-fold, and 8000-fold dilutions, along with a non-treatment control of diluted ALA. The plants of ALA-treated were significantly taller than the non-treatment control. The plants of ALA-treated plants were higher in shoot fresh weight, shoot dry weight, and root dry weight than the non-treatment control. The plot of ALA-based liquid fertilizer with the 5000 -fold dilution was significantly highest in shoot fresh weight, shoot dry weight, and root dry weight. ALA-treated plants were lower in the soil Total Petroleum Hydrocarbon (TPH) concentration than the non-treatment control. The plot of ALA-based liquid fertilizer with the 5000-fold was significantly lowest in the TPH concentration. In addition, ALA-treated plants were higher in the soil dehydrogenase activity (DHA) than the non-treatment control. The plot of ALA-based liquid fertilizer with the 5000-fold was significantly highest in the TPH concentration. This study indicated that ALA-applied zinnia-grown oil-contaminated soil is more effective than not. The remediation in oil-contaminated soil with ALA-based liquid fertilizer is more effective than the non-treatment control; furthermore, ALA application with 5000-fold dilution was most suitable in oil-contaminated soil among other plots.
\end{abstract}

\section{Keywords}

Phytoremediation, Zinnia, 5-Aminolevulinic Acid, Soil Total Petroleum Hydrocarbon (TPH) Concentration, Soil Dehydrogenase Activity (DHA) 


\section{Introduction}

Petroleum is an essential substance and is used as fuel or lubricant for a variety of purposes. The broad application of petroleum, however, leads to soil and ground water contamination in many places. Unfortunately, this wide-spread contamination has received limited research to date [1]. Oil-contamination of soil and groundwater negatively impacts human and environmental health [2], land deals, and other economic processes [3] [4]. Therefore, the Ministry of the Environment in Japan issued countermeasure guidelines and legal regulations on soil contamination by petroleum [5].

5-Aminolevulinic acid (ALA) is a key precursor in the biosynthesis of porphyrins, such as chlorophyll and heme, and may aid in the bioremediation of such contamination. The formation of ALA limits the rate of porphyrin biosynthesis [6] [7], as ALA levels concentrations are very low in vivo [8] [9]. In plants, ALA is synthesized from glutamate and appears to be highly regulated; this reaction requires a glutamyl-tRNA intermediate as well as ATP and NADPH cofactors [6] [7]. In enzyme preparations from Chlorella vulgaris [9] and higher plants [8], this step is inhibited by heme when supplied in the micromolar concentration range.

When treated with relatively higher concentrations, ALA has clear herbicidal properties. High ALA concentrations lead to the accumulation of several chlorophyll intermediates, such as protochlorophyllide and protoporphyrin IX [6] [10] [11] [12]. Most studies focusing on the physiological effects and herbicidal properties of ALA used higher concentrations (i.e. 5 - $40 \mathrm{mM}$ ) than what is found in vivo [13] [14] [15] [16] [17]. However, ALA stimulates plant growth at relatively lower concentrations [18]-[24]. Hotta et al. (1997b) [25] reported that foliar applications of $6 \mathrm{mM}$ ALA damaged radish leaves, whereas applications of $<1.8 \mathrm{mM}$ increased radish growth and left the leaves undamaged. When using $0.1-1 \mathrm{ppm}$ ALA for root applications, $30-100 \mathrm{ppm}$ in foliar sprays, and 10 $100 \mathrm{~g} / 10$ in soil treatments. Hotta et al. (1997a) [18] found that rice, corn, kidney bean, and radish seedlings grew an additional $10 \%-50 \%$.

The growth benefits of ALA may be due to its stimulation of photosynthesis [26] [27] [28]. Low ALA concentrations (i.e. $0.18-0.6 \mathrm{mM}$ ) have a variety of beneficial physiological effects to plants, including improved chlorophyll synthesis, photosynthetic activity, growth rates, respiration efficiency, and growth regulation [25] [29].

In terms of bioremediation, the degree of which oil-contaminated soils can be purified by plants (i.e. phytoremediation) is dependent on root growth. Kaimi et al. (2006) [30] reported that the rate of total petroleum hydrocarbon (TPH) reduction is greatest when root growth is most active and decreases as root growth slows. Kaimi et al. (2006) [30] and their team further suggested that root growth contributes to TPH degradation through the stimulation of microbial activity in the oil-contaminated soil.

The increased rates of photosynthesis and growth in ALA-treated plants 
would promote root growth, potentially stimulating microbial activity and TPH degradation in contaminated soil. Therefore, this study aims to discern the effect that ALA has on the growth and phytoremediation efficiency of Zinnia hybrida in oil-contaminated soil.

\section{Materials and Methods}

\subsection{Preparation of Plant and Contaminated Soil}

We previously studied 33 species of ornamental flowers and found that Zinnia hybrida exhibited the greatest phytoremediation capability within oil-contaminated soil [31]. Seeds of the $Z$. hybrida cultivar "Profusion White" were purchased from Sakata Seed Corporation (Yokohama, Japan). This greenhouse experiment was conducted at Meiji University's experimental farm for $18 \mathrm{w}$.

We used commercial black soil. This type of soil, which has low air permeability and drainage but high water and fertilizer retention, is highly versatile and widely distributed throughout Japan. In a greenhouse, the soil was air dried for 3 $\mathrm{w}$ (until its moisture content was below $1 \%[\mathrm{w} / \mathrm{w}]$ ), passed through $2 \mathrm{~mm}$ sieves, and stirred. Diesel oil was added uniformly with a pump sprayer. Contaminated soil was stirred once every $2 \mathrm{~d}$ for $14 \mathrm{~d}$. The remaining oil particles were volatilised to prevent the negative effects of low molecular weight hydrocarbons on early plant growth [32]. For testing $Z$. hybrida's remediation capability, we used an oil concentration of $4 \%$ by weight. The initial soil TPH concentration following volatilization was $9040 \mathrm{mg}$ diesel $\mathrm{kg}^{-1}$ soil.

\subsection{ALA Fertilizer Treatments}

Similar to methods described by Mori and Chino (2018) [24], we treated soil with four different concentrations of ALA-based liquid fertilizer: 1500-fold (1500 plot), 5000-fold (5000 plot), and 8000-fold (8000 plot) dilutions, along with a non-treatment control $(\mathrm{N}$ plot). Soil $(3 \mathrm{~L})$ was placed in each $1 / 5000 \mathrm{a}$ Wagner pot. A commercial delayed release fertilizer $\left(6 \% \mathrm{~N}, 40 \% \mathrm{P}_{2} \mathrm{O}_{5}, 6 \% \mathrm{~K}_{2} \mathrm{O}\right.$, $15 \% \mathrm{Mg}$; Company, Location) was mixed into the soil at a rate of $8 \mathrm{~g} \cdot \mathrm{L}^{-1}$. Eight seeds were planted for each treatment and, after germination, thinned to two plants per pot. All pots were irrigated with $300 \mathrm{~mL}$ of water every $1-2 \mathrm{~d}$, keeping the soil surface moist and avoiding run-off. Once per week, $300 \mathrm{~mL}$ of 500 -fold diluted fertiliser $\left(6 \% \mathrm{~N}, 10 \% \mathrm{P}_{2} \mathrm{O}_{5}, 5 \% \mathrm{~K}_{2} \mathrm{O}\right.$; Company, Location) was applied instead of water. Following $60 \mathrm{~d}$ after seedling, when $\sim 8$ leaves developed, ALA-based liquid fertilizer (Penta keep-V, Seiwa, Co., Ltd., Tochigi, Japan) was sprayed until shoots were moist; water was used on the control.

\subsection{Plant Measurements}

After $18 \mathrm{w}$, plants were harvested and analyzed for height, shoot fresh weight, shoot and root dry weight, soil dehydrogenase activity (DHA), and soil TPH concentration. At harvest, four pots per treatment were used for plant measurements. We measured the heights of the two plants in each pot, giving 8 plant 
height measurements per treatment. Roots were carefully washed. All the shoots and roots were harvested from each pot and the roots were washed carefully. The total dry weights of shoots and roots in each pot were measured after oven and plant matter was dried at $80^{\circ} \mathrm{C}$ for $3 \mathrm{~d}$; fresh and total dry weights of shoots and roots were measured per pot.

\subsection{Analysis of Total Petroleum Hydrocarbon (TPH) Concentrations}

Soil TPH concentrations were measured using guidelines from the Ministry of the Environment of Japan [5]; for details, see Ozawa et al. [31]. Plant roots were removed prior to analysis, which was repeated in triplicate for each sample. A gas chromatograph-hydrogen ionization detector (GC-FID, GC-2010, Shimadzu Corporation) was used to measure soil TPH concentrations. The soil in each pot was stirred and about $30 \mathrm{~g}$ was collected. For the extraction of TPH from the soil, the soil was dried in a $30^{\circ} \mathrm{C}$ incubator (IN802, Yamato Kagaku Co., Ltd.) for 4 days to dehydrate the soil, $5 \mathrm{~g}$ was weighed in a $50 \mathrm{~mL}$ triangular flask, $15 \mathrm{~mL}$ of carbon disulfide (Wako Pure Chemical Industries, Ltd.) was added and extracted with shaking for 30 minutes, and the supernatant was allowed to stand for 2 hours. After the second and subsequent times, the incubation time was set at $1 \mathrm{~h}$ and the procedure was repeated three times, the extracted solution was scalped up to $50 \mathrm{~mL}$. Unlike the method presented in the Guidelines for Oil Pollution Control (Ministry of the Environment, 2006), incubators were used for soil dewatering rather than anhydrous sodium sulfate, and extraction was performed three times before scale-up. The reasons for this are that light oil does not volatilize even after drying in the furnace, and we thought that three extractions might improve the extraction efficiency. The filtrate was filtered through a $0.45 \mu \mathrm{m}$ pore size membrane filter (Millex ${ }^{\oplus} \mathrm{LH} 0.45 \mu \mathrm{m}$, Merck Ltd.) and the filtrate was injected into the GC-FID. The carrier gas was helium, and $1 \mu \mathrm{L}$ of the sample extracted from the soil was injected in a splitless manner. Sample preparation and injection were performed using an auto-injector (AOC-20i, Shimadzu Corporation), and two replicates of analysis were performed per sample. The temperature program was held at $35^{\circ} \mathrm{C}$ for $5 \mathrm{~min}$ and then raised to $320^{\circ} \mathrm{C}$ at $10^{\circ} \mathrm{C} / \mathrm{min}$. The column is a capillary column (Intercap 1MS, GL Science) with a liquid phase of $5 \%$ phenylmethyl silicon, $30 \mathrm{~m}$ long, $0.32 \mathrm{~mm}$ inside diameter, and $0.25 \mu \mathrm{m}$ thickness.

\subsection{Analysis of Soil Dehydrogenase Activity (DHA)}

Plant roots were removed prior to analysis. Soil DHA levels were determined using the method of Hayase (1992) [33], modified as previously described in Ozawa et al. (2015) [31]. First, the soil in each pot was stirred and about $30 \mathrm{~g}$ was collected. $1 \mathrm{~mL}$ of $0.25 \mathrm{M}$ Tris buffer (Sigma Aldrich) prepared with hydrochloric acid (Kokusan Chemical Co., Ltd.) at $\mathrm{pH} 6.8$ to $1 \mathrm{~g}$ of soil and $0.4 \%$ 2-(4-iodophenyl)-3-(4-nitrophenyl)5-phenyltetrazolium chloride (INT) (Wako Pure Chemical Industries, Ltd.).) and $50 \mu \mathrm{L}$ of $1 \%$ glucose (Wako Pure Chemical 
Industries, Ltd.) were added to a $100-\mathrm{mL}$ test tube, sealed with plastic wrap, and incubated for 24 hours at $30^{\circ} \mathrm{C}$ in the dark. Then, $10 \mathrm{~mL}$ of methanol (Wako Pure Chemical Industries, Inc.) was added to stop the enzymatic reaction, and the enzyme reaction was stopped, stirred in a vortex mixer (Titec Corporation) for 1 minute, and left to stand still for approximately 10 minutes, and the supernatant was filtered. Approximately $4 \mathrm{~mL}$ of filtrate was measured at $485 \mathrm{~nm}$ using a spectrophotometer (UV-1700, Shimadzu Corporation) to analyse the change from INT to iodonitrotetrazolium formazan (INTF), which has a high reduction activity. For the control area, the contaminated soil was sterilized by autoclave and then treated.

\subsection{Statistical Analyses}

Data are presented as means \pm Standard deviation (SD). All data, except plant height $(n=8)$, were analysed at the pot level $(n=4)$ using a one-way analysis of variance and Fisher's least significant difference (LSD) test. The data were analysed using Excel Statistics 2012 (Social Survey Research Information Co., Ltd., Tokyo, Japan) and an $\alpha$ of 0.05 .

\section{Results}

\subsection{Chemical and Biological Properties of Black Soil}

Chemical properties of black soil are shown in Table 1. The TC, TN, TP, TK content values of the black soil were 59,520, 2692, 677, and $1106 \mathrm{mg} \cdot \mathrm{kg}^{-1}$, respectively. $\mathrm{C} / \mathrm{N}$ ratio value of the black soil was 22.1 . Furthermore, $\mathrm{NO}_{3}^{-}-\mathrm{N}, \mathrm{NH}_{4}^{+}-\mathrm{N}$, SP, and SK values of the black soil were $9.0,0,12.0$, and $57.0 \mathrm{mg} \cdot \mathrm{kg}^{-1}$, respectively. In addition, $\mathrm{pH}$ was 5.5 . EC was $0.14 \mathrm{mS} \mathrm{cm}^{-1}$.

Biological properties of black soil are shown in Table 2. Bacterial biomass number value was not detected. $\mathrm{NH}_{4}^{+}-\mathrm{N}$ and $\mathrm{NO}_{2}^{-}-\mathrm{N}$ oxidation activity values were 7.0, and 27.0, respectively. $\mathrm{N}$ and $\mathrm{P}$ circulation activity values were 1.0 , and 0 points, respectively.

Table 1. Chemical properties of black soil. ${ }^{\mathrm{z}}$ Mean \pm standard deviation of a sample (TC, TN, TP, TK, $\mathrm{C} / \mathrm{N} \mathrm{ratio}, \mathrm{NO}_{3}^{-}-\mathrm{N}, \mathrm{NH}_{4}^{+}-\mathrm{N}$, SP, SK, $\mathrm{pH}$, and EC: $\mathrm{n}=4$ ).

\begin{tabular}{|c|c|c|c|c|c|c|c|c|c|c|c|}
\hline & $\begin{array}{c}\text { Total C } \\
\left(\mathrm{mg} \cdot \mathrm{kg}^{-1}\right)\end{array}$ & $\begin{array}{c}\text { Total N } \\
\left(\mathrm{mg} \cdot \mathrm{kg}^{-1}\right)\end{array}$ & $\begin{array}{c}\text { Total P } \\
\left(\mathrm{mg} \cdot \mathrm{kg}^{-1}\right)\end{array}$ & $\begin{array}{c}\text { Total K } \\
\left(\mathrm{mg} \cdot \mathrm{kg}^{-1}\right)\end{array}$ & $\begin{array}{l}\mathrm{C} / \mathrm{N} \\
\text { ratio }\end{array}$ & $\begin{array}{c}\mathrm{NO}_{3}^{-}-\mathrm{N} \\
\left(\mathrm{mg} \cdot \mathrm{kg}^{-1}\right)\end{array}$ & $\begin{array}{c}\mathrm{NH}_{4}^{+}-\mathrm{N} \\
\left(\mathrm{mg} \cdot \mathrm{kg}^{-1}\right)\end{array}$ & $\begin{array}{c}\text { Available } \\
\text { phosphoric acid } \\
\left(\mathrm{mg} \cdot \mathrm{kg}^{-1}\right)\end{array}$ & $\begin{array}{c}\text { Exchangeable } \\
\text { potassium } \\
\left(\mathrm{mg} \cdot \mathrm{kg}^{-1}\right)\end{array}$ & $\mathrm{pH}$ & $\begin{array}{c}\mathrm{EC} \\
\left(\mathrm{mS} \cdot \mathrm{cm}^{-1}\right)\end{array}$ \\
\hline \multirow{3}{*}{ Black soil } & 59,520 & 2692 & 677 & 1106 & 22.1 & & & & & & \\
\hline & \pm & \pm & \pm & \pm & \pm & $9.0 \pm 0.8$ & $0 \pm 0.0$ & $12.0 \pm 2.45$ & $57 \pm 1.63$ & $5.5 \pm 0.1$ & $0.14 \pm 0.02$ \\
\hline & $8.16^{\mathrm{Z}}$ & 0.12 & 1.63 & 2.45 & 0.08 & & & & & & \\
\hline
\end{tabular}

Table 2. Biological properties of black soil. ${ }^{\mathrm{z}} \mathrm{Mean} \pm$ standard deviation of a sample (bacterial biomass, $\mathrm{NH}_{4}^{+}-\mathrm{N}$ oxidation activity, $\mathrm{NO}_{2}^{-}-\mathrm{N}$ oxidation activity, $\mathrm{N}$ circulation activity, and $\mathrm{P}$ circulation activity: $\mathrm{n}=4$ ).

\begin{tabular}{cccccc}
\hline & $\begin{array}{c}\text { Bacterial biomass } \\
\left(\times 10^{8} \text { cells } \cdot \mathrm{g}^{-1}\right)\end{array}$ & $\begin{array}{c}\mathrm{NH}_{4}^{+} \text {oxidation } \\
\text { activity (point) }\end{array}$ & $\begin{array}{c}\mathrm{NO}_{2}^{-} \text {oxidation } \\
\text { activity (point) }\end{array}$ & $\begin{array}{c}\mathrm{N} \text { circulation } \\
\text { activity (point) }\end{array}$ & $\begin{array}{c}\mathrm{P} \text { circulation } \\
\text { activity (point) }\end{array}$ \\
\hline Black soil & n.d $\pm 0^{\mathrm{z}}$ & $7.0 \pm 0.82$ & $27.0 \pm 1.63$ & $1.0 \pm 0$ & $0 \pm 0.0$ \\
\hline
\end{tabular}




\subsection{Comparison of Height, Weight of Zinnia hybrida}

The plant heights, shoot fresh weights, and shoot and root dry weights after $18 \mathrm{w}$ with $\mathrm{N}, 1500,5000$, and 8000 plots are shown in Table 3. Plant height values of $\mathrm{N}, 1500,5000$, and 8000 plots were 28.5, 32.2, 33.7, and $32.1 \mathrm{~cm}$, respectively. Shoot fresh weight values of those plots were 17.07, 29.32, 35.84, and 27.77 g. pot $^{-1}$, respectively. Shoot dry weight values of those plots were $6.78,7.18,8.12$, and $6.80 \mathrm{~g} \cdot$ pot $^{-1}$, respectively. Root dry weight values of those plots were 1.28, $1.69,2.45$, and $1.37 \mathrm{~g} \cdot \operatorname{pot}^{-1}$, respectively. ALA-treated plants were significantly taller than the control; however, there were no significant differences among ALA-treated plots. Root and shoot fresh and dry weights within the 5000 plot were significantly higher than the control 5000 plot and significantly lower at $\mathrm{N}$ plot.

\subsection{Comparison of Soil TPH Concentrations and Soil DHA Levels}

Soil TPH concentration and soil DHA level of N, 1500, 5000, and 8000 plots are shown in Table 4. Soil TPH concentration values of those plots were 6143.2, $4638.4,3872.3$, and $4819.2 \mathrm{mg} \cdot \mathrm{kg}^{-1}$-soil, respectively. Soil DHA level values of those plots were $9.31,12.07,13.86$, and $11.85 \mathrm{mg} \mathrm{INTF} \mathrm{g}^{-1} \mathrm{DW} \mathrm{h}^{-1}$, respectively. The DHA levels were higher at 5000 plot and lower at $\mathrm{N}$ pot (Table 4). In contrast, the TPH concentrations were significantly lower in 5000 plot and significantly higher within thin $\mathrm{N}$ plot (Table 4). This negative correlation between soil TPH and DHA levels is consistent with the literature [32].

Table 3. Plant height $(\mathrm{n}=8)$ and weights $(\mathrm{n}=4)$ of $Z$. hybrida after $18 \mathrm{w}$ of diluted ALA (plot) treatments.

\begin{tabular}{ccccc}
\hline Plot & $\begin{array}{c}\text { Plant height } \\
(\mathrm{cm})\end{array}$ & $\begin{array}{c}\text { Shoot fresh } \\
\text { weight } \\
\left(\mathrm{g} \cdot \mathrm{pot}^{-1}\right)\end{array}$ & $\begin{array}{c}\text { Shoot dry } \\
\text { weight } \\
\left(\mathrm{g} \cdot \mathrm{pot}^{-1}\right)\end{array}$ & $\begin{array}{c}\text { Root dry } \\
\text { weight } \\
\left(\mathrm{g} \cdot \mathrm{pot}^{-1}\right)\end{array}$ \\
\hline $\mathrm{N}$ & $28.5 \pm 5.6 \mathrm{~b}$ & $17.07 \pm 1.63 \mathrm{c}$ & $6.78 \pm 0.71 \mathrm{~b}$ & $1.28 \pm 0.48 \mathrm{c}$ \\
1500 & $32.2 \pm 4.3 \mathrm{a}$ & $29.32 \pm 1.25 \mathrm{~b}$ & $7.18 \pm 0.38 \mathrm{~b}$ & $1.69 \pm 0.42 \mathrm{~b}$ \\
5000 & $33.7 \pm 6.9 \mathrm{a}$ & $35.84 \pm 3.06 \mathrm{a}$ & $8.12 \pm 0.58 \mathrm{a}$ & $2.45 \pm 1.32 \mathrm{a}$ \\
8000 & $32.1 \pm 8.7 \mathrm{a}$ & $27.77 \pm 0.40 \mathrm{~b}$ & $6.80 \pm 0.85 \mathrm{~b}$ & $1.37 \pm 0.48 \mathrm{c}$ \\
\hline
\end{tabular}

${ }^{*}$ letters represent significantly different $(p<0.05)$ groups calculated using Fisher's LSD.

Table 4. Contaminated soil TPH concentrations and DHA levels $(\mathrm{n}=4)$ after $18 \mathrm{w}$ of $Z$. hybrida growth treated with different concentrations (plots) of ALA.

\begin{tabular}{ccc}
\hline Plot & Soil TPH concentration $\left(\mathrm{mg} \cdot \mathrm{kg}^{-1}\right.$-soil $)$ & Soil DHA level $\left({\mathrm{mg} \mathrm{INTF} \mathrm{g}^{-1} \mathrm{DW} \mathrm{h}}^{-1}\right)$ \\
\hline $\mathrm{N}$ & $6143.2 \pm 50.8 \mathrm{a}$ & $9.31 \pm 0.75 \mathrm{~b}$ \\
1500 & $4638.4 \pm 53.3 \mathrm{~b}$ & $12.07 \pm 0.84 \mathrm{ab}$ \\
5000 & $3872.3 \pm 89.8 \mathrm{c}$ & $13.86 \pm 0.15 \mathrm{a}$ \\
8000 & $4819.2 \pm 94.6 \mathrm{~b}$ & $11.85 \pm 0.66 \mathrm{ab}$ \\
\hline
\end{tabular}

${ }^{*}$ letters represent significantly different $(p<0.05)$ groups calculated using Fisher's LSD. 


\section{Discussion}

Plant growth is enhanced at low concentrations (i.e. 30 - 100 ppm to $90-120$ $\mu \mathrm{mol} \cdot \mathrm{L}^{-1}$ ) of ALA treatments in a variety of plants [18]-[25] [29]. Several reports suggested that these stimulatory growth effects may be related to elevated chlorophyll synthesis, improved photosynthetic efficiency, increased net photosynthetic rate, and reduced respiration [20] [21] [25] [26] [27] [28] [29] [34] [35] ALA concentrations as little as $3 \mathrm{mM}$ have even encouraged the accumulation of $\mathrm{Chl} \mathrm{b}$ and LHC II apoproteins, stimulated chlorophyll and phycocyanin synthesis, and lead to increased growth [35] [36]. These reports are consistent with our findings, that ALA applications increase the growth of $Z$. hybrida.

The rhizosphere is an active environment that, through interactions among plants, microorganisms, and other organic substances, can break down contaminants, such as oil [37]. In fact, soil TPH decomposes more rapidly in the rhizosphere than in the non-rhizosphere [37] [38]. Root exudates, such as carboxylic acid, amino acid, protein, and sugars, may provide nutrients for microorganisms, enhancing microbial activity and increasing rhizosphere degradation activity. Root surfaces also become the location of growth for microorganisms because of abundant nutrients of the roots exudate, such as carboxylic acid, amino acid, protein, and sugars [32]. The rate of TPH degradation is greatest during the most active period of root growth and decreases when root growth declines [32] [39]. Our results support the idea that root growth increases the degree of purification in contaminated soils by oil.

ALA-treatments enhanced $Z$. hybrida photosynthesis activity and increased exudates from plant roots. These exudates may have provided nutrients for microorganisms and enhanced microbial activity in the oil-contaminated soil, resulting in the decreased TPH concentrations we observed. This effect was the highest at the 5000-fold diluted concentration, similar to the findings of Mori and Chino (2018) [24].

\section{Conclusion}

We sprayed ALA to the stems and leaves of $Z$. hybrida at different dilution concentrations of ALA: 1500-fold, 5000-fold, and 8000-fold dilutions, along with a non-treatment control of diluted ALA in oil-contaminated soil. The results showed that in plant growth, soil TPH was smaller and soil DHA level was larger when ALA was sprayed than when it was not sprayed. These results indicate that spraying ALA in combination with the growth of zinnia improves the purification effect of oil-contaminated soil. The best remediation effect was achieved by the 5000-FLOD dilution of ALA.

\section{Conflicts of Interest}

The authors declare no conflicts of interest regarding the publication of this paper. 


\section{References}

[1] Baoune, H., El Hadj-Khelil, A.O., Pucci, G., Sineli, P., Loucif, L. and Polti, M.A. (2018) Petroleum Degradation by Endophytic Streptomyces spp. Isolated from Plants Grown in Contaminated Soil of Southern Algeria. Ecotoxicology and Environmental Safety, 147, 602-609. https://doi.org/10.1016/j.ecoenv.2017.09.013

[2] Dowling, D.N. and Doty, S.L. (2009) Improving Phytoremediation through Biotechnology. Current Opinion in Biotechnology, 20, 204-206.

https://doi.org/10.1016/j.copbio.2009.03.007

[3] Fatima, K., Afzal, M., Imran, A. and Khan, Q.M. (2015) Bacterial Rhizosphere and Endosphere Populations Associated with Grasses and Trees to Be Used for Phytoremediation of Crude Oil Contaminated Soil. Bulletin of Environmental Contamination and Toxicology, 94, 314-320. https://doi.org/10.1007/s00128-015-1489-5

[4] Panchenko, L., Muratova, A. and Turkovskaya, O. (2017) Comparison of the Phytoremediation Potentials of Medicago falcata L. and Medicago sativa L. in Aged Oil-Sludge-Contaminated Soil. Environmental Science and Pollution Research (International), 24, 3117-3130. https://doi.org/10.1007/s11356-016-8025-y

[5] The Geo-Environmental Protection Center (2006) The TPH Test Methods Using GC-FID, Guidelines against Oil Pollution by the Ministry of Environment. The Chemical Daily Co. Ltd., Tokyo, 99-115. (In Japanese)

[6] Castelfranco, P.A., Rich, P.M. and Beale, S.I. (1974) The Abolition of the Lag Phase in Greening Cucumber Cothyledons by Exogenous $\delta$-Aminolevulinic Acid. Plant Physiology, 53, 615-618. https://doi.org/10.1104/pp.53.4.615

[7] Beale, S.I. (1990) Biosynthesis of the Tetrapyrrole Pigment Precursor, $\delta$-Aminolevulinic Acid, from Glutamate. Plant Physiology, 93, 1273-1279.

https://doi.org/10.1104/pp.93.4.1273

[8] Chereskin, B.M. and Castelfranco, P.A. (1982) Effects of Iron and Oxygen on Chlorophyll Biosynthesis: II. Observations on the Biosynthetic Pathway in Isolated Etiochloroplasts. Plant Physiology, 69, 112-116. https://doi.org/10.1104/pp.69.1.112

[9] Weinstein, J.D. and Beale, S.I. (1985) Enzymatic Conversion of Glutamate to $\delta$-Aminolevulinic Acid in Soluble Extracts of the Unicellular Green Alga, Chlorella vulgaris. Archives of Biochemistry and Biophysics, 239, 454-464. https://doi.org/10.1016/0003-9861(85)90299-1

[10] Sisler, E.C. and Klein, W.H. (1963) The Effect of Age and Various Chemicals on the Lag Phase of Chlorophyll Synthesis in Dark Grown Bean Seedlings. Physiologia Plantarum, 16, 315-322. https://doi.org/10.1111/j.1399-3054.1963.tb08312.x

[11] Sundquvist, C. (1969) Transformation of Protochlorophyllide, Formed from Exogenous $\delta$-Aminolevulinic Acid in Continuous Light and Flashlight. Physiologia Plantarum, 22, 147-156. https://doi.org/10.1111/j.1399-3054.1969.tb07850.x

[12] Nadler, K. and Granick, S. (1970) Controls on Chlorophyll Synthesis in Barley. Plant Physiology, 46, 240-246. https://doi.org/10.1104/pp.46.2.240

[13] Rebeiz, C.A., Montazer-Zouhoor, A., Jopen, H.J. and Wu, S.M. (1984) Photodynamic Herbicides: Concept and Phenomenology. Enzyme and Microbial Technology, 6, 390-401. https://doi.org/10.1016/0141-0229(84)90012-7

[14] Rebeiz, C.A., Reddy, K.N., Nandihalli, U.B. and Velu, J. (1990) Tetrapyrrole-Dependent Photodynamic Herbicides. Photochemistry and Photobiology, 52, 1099-1117. https://doi.org/10.1111/j.1751-1097.1990.tb08451.x

[15] Askira, Y., Rubin, B. and Rabinowitch, H.D. (1991) Differential Response to the Herbicidal Activity of $\delta$-Aminolevulinic Acid in Plants with High and Low SOD 
Activity. Free Radical Research Communications, 12-13, 837-843. https://doi.org/10.3109/10715769109145865

[16] Kittsteiner, U., Mostowska, A. and Rudinger, W. (1991) The Greening Process in Cress Seedlings. Pigment Accumulation and Ultrastructure after Application of 5-Aminolevulinate and Complexing Agents. Physiologia Plantarum, 81, 139-147. https://doi.org/10.1111/j.1399-3054.1991.tb01726.x

[17] Chakraborty, N. and Tripathy, B.C. (1992) Involvement of Singlet Oxygen in 5-Aminolevulinic Acid Induced Photodynamic Damage of Cucumber Chloroplast. Plant Physiology, 98, 7-11. https://doi.org/10.1104/pp.98.1.7

[18] Hotta, Y., Watanabe, K., Tanaka, T., Takeuchi, Y. and Konnai, M. (1997) Effects of 5-Aminolevulinic Acid on Growth of Plant Seedlings. Journal of Pesticide Science, 22, 102-107. https://doi.org/10.1584/jpestics.22.102

[19] Sasaki, K., Watanabe, M., Tanaka, T. and Tanaka, T. (2002) Biosynthesis, Biotechnological Production and Applications of 5-Aminolevulinic Acid. Applied Microbiology and Biotechnology, 58, 23-29. https://doi.org/10.1007/s00253-001-0858-7

[20] Youssef, T. and Awad, M.A. (2008) Mechanisms of Enhancing Photosynthetic Gas Exchange in Date Palm Seedlings (Phoenix dactylifera L.) under Salinity Stress by a 5-Aminolevulinic Acid-Based Fertilizer. Journal of Plant Growth Regulation, 27, 1-9. https://doi.org/10.1007/s00344-007-9025-4

[21] Xu, F., Zhu, J., Cheng, S., Zhang, W. and Wang, Y. (2010) Effect of 5-Aminolevulinic Acid on Photosynthesis, Yield, Nutrition and Medicinal Values of Kudzu (Pueraria phaseoloides). Tropical Grassland, 44, 260-265.

[22] Al-Qurashi, A.D. and Awad, M.A. (2011) 5-Aminolevulinc Acid Increases Tree Yield and Improves Fruit Quality of "Rabia" and "Sukkariat-Yanbo" Date Palm Cultivars under Hot Arid Climate. Scientia Horticulturae, 129, 441-448. https://doi.org/10.1016/j.scienta.2011.04.014

[23] Yonezawa, T., Sunohara, Y. and Matsumoto, H. (2015) Involvement of Heme Synthesis in the Growth Stimulation of Maize Seedlings by 5-Aminolevulinic Acid. Weed Biology and Management, 15, 53-60. https://doi.org/10.1111/wbm.12064

[24] Mori, S. and Chino, H. (2018) Effects of $\mathrm{CO}_{2}$ Enrichment and 5-Aminolevulinic Acid-Based Fertilizer Application on Early Growth of Limonium sinuatum (L.) Mill. under Environmental Control. Shokubutsu Kankyo Kogaku, 30, 165-171. https://doi.org/10.2525/shita.30.165

[25] Hotta, Y., Tanaka T., Takaoka, H., Takeuchi, Y. and Konnai, M. (1997) Promotive Effects of 5-Aminolevulinic Acid on the Yield of Several Crops. Plant Growth Regulation, 22, 109-114. https://doi.org/10.1023/A:1005883930727

[26] Nishihara, E., Kondo, K., Parvez, M.M., Takahashi, K., Watanabe, K. and Tanaka, K. (2003) Role of 5-Aminolevulinic Acid (ALA) on Active Oxygen-Scavenging System in NaCl-Treated Spinach (Spinacia oleracea). Journal of Plant Physiology, 160, 1085-1091. https://doi.org/10.1078/0176-1617-00991

[27] Wang, L.J., Jiang, W.B. and Huang, B.J. (2004) Promotion of 5-Aminolevulinic Acid on Photosynthesis of Melon (Cucumis melo) Seedlings under Low Light and Chilling Stress Condition. Physiologia Plantarum, 121, 258-264. https://doi.org/10.1111/j.0031-9317.2004.00319.x

[28] Memon, S.A., Hou, X.L. and Wang L.J. (2009) Promotion Effect of 5-Aminolevulinic Acid on Chlorophyll, Antioxidant Enzymes and Photosynthesis of Pakchoi (Brassica campestris ssp. chinensis var. communis Tsen et Lee). Acta Physiologia Plantarum, 31, 51-57. https://doi.org/10.1007/s11738-008-0198-7

[29] Hotta, Y., Tanaka, T., Takaoka, H., Takeuchi, Y. and Konnai, M. (1997) New Physi- 
ological Effects of 5-Aminolevulinic Acid in Plants: The Increase of Photosynthesis, Chlorophyll Content, and Plant Growth. Bioscience, Biotechnology, and Biochemistry, 61, 2025-2028. https://doi.org/10.1271/bbb.61.2025

[30] Kaimi, E., Mukaidani, T., Miyoshi, S. and Tamaki, M. (2006) Ryegrass Enhancement of Biodegradation in Diesel-Contaminated Soil. Environmental and Experimental Botany, 55, 110-119. https://doi.org/10.1016/j.envexpbot.2004.10.005

[31] Ozawa, S., Ikeura, H., Kaimi, E. and Tamaki, M. (2015) Selection of the Most Effective Cultivar of Genus Zinnia Flowers for Phytoremediation of Oil-Contaminated Soil. International Journal of Plant \& Soil Science, 4, 61-71. https://doi.org/10.9734/IJPSS/2015/13035

[32] Kaimi, E., Mukaidani, T. and Tamaki, M. (2007) Effect of Rhizodegradation in Diesel-Contaminated Soil under Different Soil Conditions. Plant Production Science, 10, 105-111. https://doi.org/10.1626/pps.10.105

[33] Hayase, K. (1992) Measurement of Enzyme Activity in Soil. Experimental Methods in Soil Microbiology New Edition. Youken-dou, Tokyo.

[34] Sun, Y.P., Liu, J., Cao, R.X., Huang, Y.J., Hall, A.M., Guo, C.B. and Wang, L.J. (2017) Effects of 5-Aminolevulinic Acid Treatment on Photosynthesis of Strawberry. Photosynthetica, 55, 276-284. https://doi.org/10.1007/s11099-016-0667-y

[35] Tanaka, Y., Tanaka, A. and Tsuji, H. (1992) Stabilization of Apoproteins of Light-Harvesting Chlorophyll a/b-Protein Complex by Feeding 5-Aminolevulinic Acid under Intermittent Illumination. Plant Physiology and Biochemistry, 30, 365-370.

[36] Sasaki, K., Marquez, F.J., Nishio, N. and Nagai, S. (1995) Promotive Effect of 5-Aminolevulinic Acid on the Growth and Photosynthesis of Spirulina Platensis. Journal of Fermentation and Bioengineering, 79, 453-457. https://doi.org/10.1016/0922-338X(95)91261-3

[37] Bianchi, V. and Ceccanti, A. (2010) A Three Components System (TRIAS) in the Phytoremediation of Polluted Environmental Matrices. Toxicological \& Environmental Chemistry, 92, 477-493. https://doi.org/10.1080/02772240903036154

[38] Wang, Z., Xu, Y., Zhao, J., Li, F., Gao, D. and Xing, B. (2011) Remediation of Petroleum Contaminated Soils through Composting and Rhizosphere Degradation. Journal of Hazardous Materials, 190, 677-685. https://doi.org/10.1016/j.jhazmat.2011.03.103

[39] Banks, M.K., Kulakow, P., Schwab, A.P., Chen, Z. and Rathbone, K. (2003) Degradation of Crude Oil in the Rhizosphere of Sorghum Bicolor. International Journal of Phytoremediation, 5, 225-234. https://doi.org/10.1080/713779222 